\title{
ANALISIS KESALAHAN MENYELESAIKAN SOAL CERITA PROGRAM LINEAR DITINJAU DARI PERBEDAAN JENIS KELAMIN
}

\author{
Syaifi Nurun Nikmah \\ Haeruddin $^{2)}$ \\ Asyril ${ }^{3)}$ \\ 1), 2), 3) Program Studi Pendidikan Matematika, Universitas Mulawarman \\ Email: ${ }^{1)}$ nurunnikmah.syaifi@gmail.com \\ ${ }^{2)}$ haeruddin22@gmail.com
}

\begin{abstract}
ABSTRAK
Jenis penelitian ini adalah deskriptif kualitatif. Penelitian ini bertujuan untuk mengetahui kesalahan siswa dalam menyelesaikan soal cerita program linear. Kesalahan yang dilakukan siswa tersebut dibedakan berdasarkan jenis kelamin. Selain itu, penelitian ini juga mencari penyebab siswa melakukan kesalahan. Penelitian dilaksanakan di SMA Nabil Husein Samarinda tahun ajaran 2019/2020. Subjek penelitian ini adalah sebanyak 25 siswa kelas XI MIPA 1 dan XI MIPA 2. Objek penelitian ini adalah kesalahan-kesalahan siswa dalam menyelesaikan soal dan penyebab kesalahan tersebut terjadi. Pengumpulan data dilakukan melalui observasi, tes tertulis, dan wawancara. Hasil penelitian menunjukkan bahwa (1) sebanyak $21 \%$ siswa laki-laki dan $10 \%$ siswa perempuan melakukan kesalahan menginterpretasikan makna redaksi soal (membaca). (2) Sebanyak 42\% siswa laki-laki dan $23 \%$ siswa perempuan melakukan kesalahan memahami informasi yang diketahui dan ditanyakan dalam soal (memahami). (3) Sebanyak 26\% siswa laki-laki dan 50\% siswa perempuan melakukan kesalahan dalam mengubah soal cerita ke dalam model program linear (transformasi). (4) Sebanyak $11 \%$ siswa laki-laki dan $17 \%$ siswa perempuan melakukan kesalahan menyelesaikan model program linear (keterampilan proses). (5) Tidak ada siswa yang melakukan kesalahan penulisan kesimpulan. Penyebab kesalahan tersebut terjadi antara lain tidak teliti dalam berhitung, tidak menguasai materi prasyarat dan sumber belajar yang belum cukup.
\end{abstract}

Kata kunci: Analisis Kesalahan, Soal Cerita Program Linear, Jenis Kelamin

\begin{abstract}
This type of research is qualitative descriptive. This research aims to determine the student errors in solving linear programming word problem. That student errors are differentiated by gender. In addition, this research also search the causes students make errors. The research was carry out at Nabil Hussein high school Samarinda in the academic year 2019/2020. This research subjects were 25 students of class $11^{\text {th }}$ MIPA-1 and class $11^{\text {th }}$ MIPA-2. This research objects are the student errors in solving problems and the causes. Data collected by observation, written test and interview. The results
\end{abstract}


showed that (1) $21 \%$ of male students and $10 \%$ of female students misinterpreted the meaning of the editorial problem (reading). (2) $42 \%$ of male students and $23 \%$ of female students misunderstood the known and asked information the problem (Comprehension). (3) $26 \%$ of male students and $50 \%$ of female students wrong in turning about the word problem into the linear programming model (transformation). (4) $11 \%$ of male students and $17 \%$ female students wrong in solving linear programming model (process skill). (5) No student was wrong in writing conclusion. The causes of these errors include not thorough in counting, not mastering the prerequisite material and insufficient learning resources.

Keywords: Error Analysis, Linear Programming Word Problem, Gender

\section{PENDAHULUAN}

Dalam rangka meningkatkan mutu pendidikan khususnya pada mata pelajaran matematika, guru sebagai fasilitator bertanggung jawab dalam memfasilitasi siswa sehingga siswa dapat menguasai materi pelajaran yang diajarkan. Namun kenyataannya masih banyak siswa yang belum menguasai materi dengan baik, sehingga menyebabkan siswa melakukan kesalahan dalam menyelesaikan soal matematika. Jika kesalahan menyelesaikan soal matematika tidak segera diatasi, maka siswa akan selalu menghadapi masalah dalam belajar matematika.

SMA Nabil Husein Samarinda merupakan sekolah dengan sistem pesantren dimana kelas untuk siswa lakilaki dan perempuan dipisah. Salah satu materi dalam pembelajaran matematika kelas XI kurikulum 2013 edisi revisi 2017 semester ganjil adalah program linear. Berdasarkan penelitian yang dilakukan Susanti, terdapat siswa yang melakukan kesalahan dalam menyelesaikan soal cerita program linear sehingga jawaban siswa perlu dianalisis (Susanti, 2017). Berdasarkan observasi yang dilakukan peneliti di SMA Nabil Husein Samarinda tahun ajaran 2018/2019, banyak siswa yang melakukan kesalahan dalam menyelesaikan soal program linear, terutama soal yang berbentuk cerita. Kesalahan yang sering dilakukan siswa berupa kesalahan dalam membuat model matematika dan kesalahan akibat kurangnya pemahaman terhadap materi prasyarat seperti operasi hitung bentuk aljabar, persamaan garis lurus, serta sistem persamaan dan pertidaksamaan linear. Selain itu, terdapat perbedaan antara siswa laki-laki dan perempuan saat proses pembelajaran berlangsung. Siswa perempuan lebih aktif dalam bertanya dibandingkan siswa laki-laki, serta siswa laki-laki cenderung malas mengerjakan tugas yang diberikan oleh guru. Hal ini sesuai dengan pendapat DeZolt dan Hull yang mengatakan bahwa dibandingkan dengan perempuan, laki-laki cenderung kurang memberikan perhatian terhadap pelajaran di kelas, kurang berusaha lebih keras dalam menyelesaikan tugas-tugas akademis, dan kurang berpartisipasi di kelas (Santrock, 2007).

Analisis kesalahan adalah suatu usaha untuk mengklasifikasi suatu penyimpangan terhadap hal yang benar (Susanti, 2017). Menurut Ellis, analisis kesalahan merupakan suatu langkah kerja yang biasanya digunakan oleh peneliti, 
dimana kegiatannya terdiri dari mengumpulkan sampel kesalahan, mengidentifikasi kesalahan yang ada dalam sampel, menjelaskan kesalahan tersebut, mengklasifikasi kesalahan, dan mengevaluasi taraf keseriusan kesalahan itu (Tarigan, 1988). Analisis Kesalahan adalah suatu cara kerja yang didasarkan pada analisis kesalahan dari orang yang sedang belajar dengan objek yang sudah ditargetkan (Setyawati, 2010). Analisis kesalahan siswa dalam menyelesaikan soal matematika adalah suatu cara untuk mengkaji hasil jawaban siswa dalam menyelesaikan soal matematika yang meliputi kegiatan mengidentifikasi kesalahan, mengklasifikasi kesalahan dan mencari penyebab kesalahan. Dalam penelitian ini, peneliti menggunakan teori Newman untuk mengklasifikasi kesalahan siswa dalam menyelesaikan soal cerita program linear. Teori Newman dirasa cocok untuk menganalisis kesalahan siswa dalam menyelesaikan soal cerita, karena tahapan-tahapan pada teori Newman sesuai dengan tahapan-tahapan dalam menyelesaikan soal cerita matematika.

Teori Newman diperkenalkan oleh seorang guru matematika di Australia bernama Anne Newman pada tahun 1977. Menurut Newman, ketika siswa berusaha untuk menjawab soal yang berbentuk soal cerita, maka siswa tersebut sudah melewati serangkaian hambatan berupa tahapan dalam menyelesaikan soal cerita, yaitu tahapan membaca soal (Reading), tahapan memahami soal (Comprehension), tahapan transformasi soal (Transformation), tahapan keterampilan proses (Process skill), dan tahapan penulisan jawaban akhir atau kesimpulan (Encoding) (White, 2010). Adapun indikator kesalahan siswa berdasarkan teori Newman dalam penelitian ini adalah sebagai berikut.

1. Kesalahan Membaca Soal

Kesalahan membaca soal dikategorikan kepada siswa yang salah menginterpretasikan makna redaksi soal sehingga siswa salah dalam menuliskan "apa yang diketahui" dan atau "apa yang ditanyakan" dalam soal.

2. Kesalahan Memahami Soal

Kesalahan memahami soal dikategorikan kepada siswa yang:

a. Tidak memahami makna kalimat yang diajukan dalam soal, seperti kalimat yang mengandung kata maksimum atau minimum.

b. Menuliskan "apa yang diketahui" dan "apa yang ditanyakan" sama persis dengan soal tetapi tidak melanjutkan proses.

c. Tidak lengkap menuliskan informasi yang diketahui dari soal.

d. Tidak lengkap menuliskan apa yang ditanyakan dalam soal.

e. Tidak menuliskan "apa yang diketahui" dan atau "apa yang ditanyakan" dalam soal dan menuliskan jawaban sembarang.

3. Kesalahan Transformasi Soal

Kesalahan transformasi soal dikategorikan kepada siswa yang:

a. Tidak mengubah informasi pada soal dalam bentuk model program linear.

b. Salah memisalkan objek pada soal yang menyebabkan salah dalam membuat fungsi kendala dan tujuan.

c. Tidak menuliskan fungsi kendala.

d. Salah menuliskan fungsi kendala. 
e. Tidak lengkap menuliskan fungsi kendala yang menyebabkan salah dalam membuat grafik daerah penyelesaiannya.

f. Tidak menuliskan fungsi tujuan.

g. Salah menuliskan fungsi tujuan.

4. Kesalahan Keterampilan Proses

Kesalahan keterampilan proses

dikategorikan kepada siswa yang:

a. Salah menentukan titik potong garis terhadap sumbu X dan sumbu Y.

b. Salah menyederhanakan persamaan atau pertidaksamaan.

c. Salah menggambar garis dari persamaan garis.

d. Salah menentukan daerah penyelesaian berdasarkan titik uji.

e. Salah menentukan titik pojok daerah penyelesaian.

f. Salah dalam proses eliminasi dan substitusi.

g. Salah menuliskan koordinat titik.

h. Salah perhitungan dalam menentukan nilai fungsi objektif.

i. Ada langkah-langkah yang dilewatkan atau tidak dituliskan.

5. Kesalahan Penulisan Kesimpulan

Kesalahan penulisan kesimpulan dikategorikan kepada siswa yang:

a. Tidak menuliskan kesimpulan.

b. Menuliskan kesimpulan yang tidak sesuai dengan permintaan soal. Kesalahan-kesalahan yang dilakukan siswa dalam menyelesaikan soal matematika perlu diperbaiki dengan melakukan analisis kesalahan. Tujuannya untuk mengetahui apa saja kesalahan yang sering dilakukan siswa dalam menyelesaikan soal matematika sehingga dapat menentukan langkah perbaikan. Hal ini dilakukan agar kesalahan yang dilakukan siswa dapat diminimalisir.

\section{METODE PENELITIAN}

Jenis penelitian yang dilaksanakan adalah penelitian deskriptif dengan metode kualitatif. Penelitian dilaksanakan pada bulan Agustus hingga Oktober 2019 di SMA Nabil Husein Samarinda. Subjek penelitian ini adalah siswa kelas XI MIPA 1 yang terdiri dari 9 siswa laki-laki dan siswa kelas XI MIPA 2 yang terdiri dari 16 siswa perempuan. Objek penelitian ini adalah kesalahan-kesalahan siswa dalam menyelesaikan soal cerita program linear dan penyebab siswa melakukan kesalahan tersebut.

Teknik pengumpulan data yang digunakan adalah observasi selama proses pembelajaran program linear, pemberian soal tes tertulis sebanyak 2 butir soal cerita program linear, dan wawancara dengan siswa yang dijadikan responden wawancara untuk memperoleh informasi penyebab siswa melakukan kesalahan. Pengambilan responden wawancara dilakukan dengan memilih masing-masing kelas 2 siswa, dengan kriteria siswa yang dipilih merupakan siswa yang menyelesaikan minimal 1 soal dan melakukan kesalahan, kedua siswa tersebut dapat mewakili secara umum setiap jenis kesalahan yang dilakukan oleh siswa lain, serta berdasarkan saran dari guru siswa tersebut dapat mengemukakan gagasannya dengan baik.

Analisis data hasil tes tertulis dilakukan dengan mengumpulkan lembar jawaban siswa yang melakukan kesalahan, mengidentifikasi dan menjelaskan kesalahan, mengklasifikasi kesalahan berdasarkan indikator kesalahan pada teori Newman dan evaluasi kesalahan. Adapun analisis data hasil wawancara dilakukan dengan 
Tabel 1. Persentase Banyaknya Kesalahan Siswa

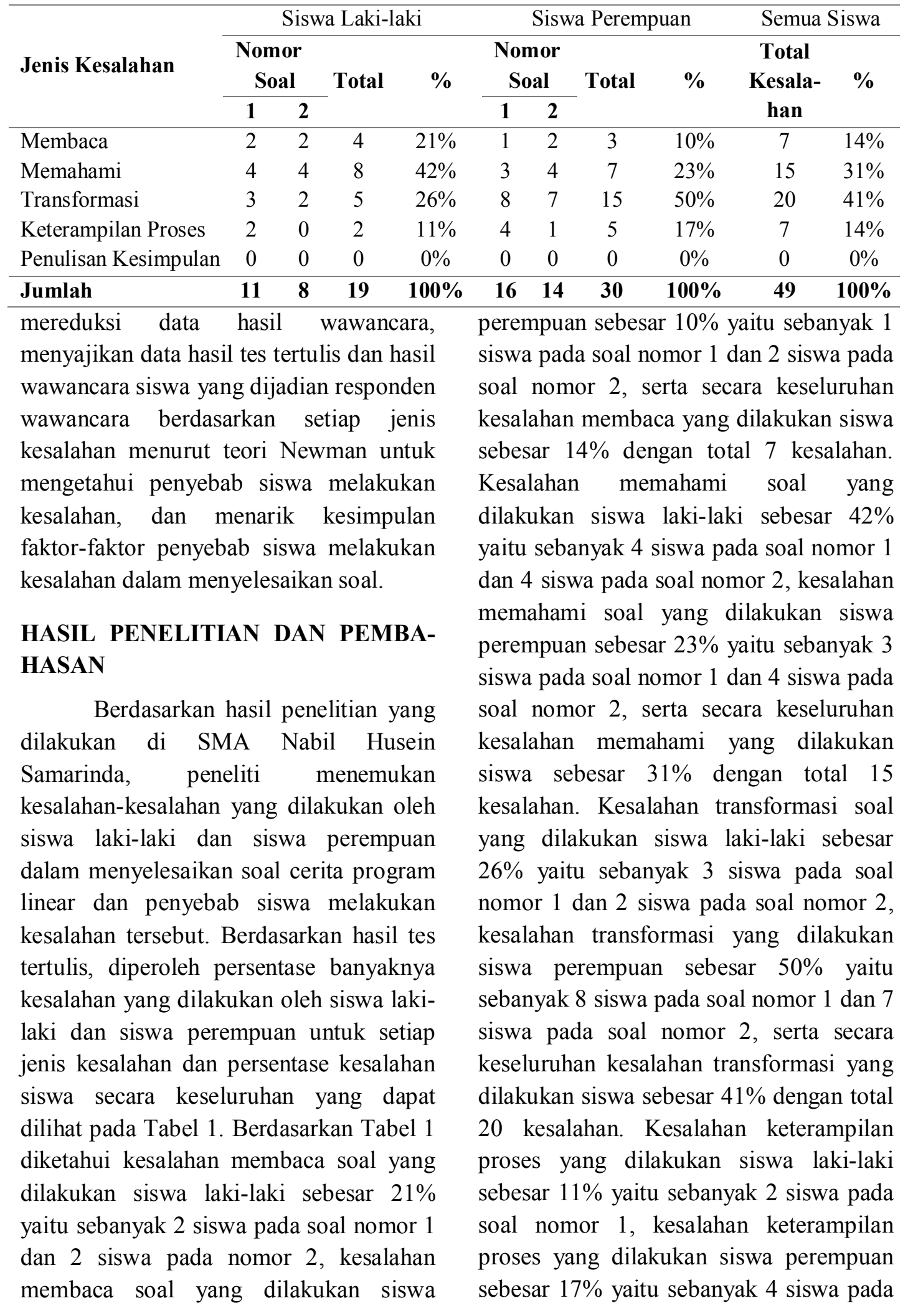


soal nomor 1 dan 1 siswa pada soal nomor 2, serta secara keseluruhan kesalahan keterampilan proses yang dilakukan siswa sebesar 14\% dengan total 7 kesalahan. Kesalahan penulisan kesimpulan yang dilakukan siswa laki-laki sebesar $0 \%$ dan siswa perempuan sebesar $0 \%$ dimana tidak ada satupun siswa yang melakukan kesalahan penulisan kesimpulan.

Kesalahan terbanyak yang dilakukan siswa laki-laki adalah kesalahan pada tahap kedua yaitu tahap memahami soal, dan kesalahan terbanyak yang dilakukan siswa perempuan adalah kesalahan pada tahap ketiga yaitu tahap transformasi soal. Hal ini menunjukkan bahwa sebagian besar siswa perempuan lebih memahami materi program linear dibandingkan dengan siswa laki-laki. Hal ini sesuai dengan pendapat DeZolt dan Hull yang mengatakan bahwa dalam menangani materi-materi akademis, perempuan cenderung lebih baik dibandingkan laki-laki (Santrock, 2007). Selain itu, baik siswa laki-laki maupun siswa perempuan tidak ada yang melakukan kesalahan penulisan kesimpulan dikarenakan siswa sudah melakukan kesalahan pada tahap-tahap sebelumnya, yaitu pada tahap membaca, memahami, transformasi, dan keterampilan proses. Secara keseluruhan, kesalahan terbanyak yang dilakukan siswa adalah kesalahan transformasi.

Berikut deskripsi kesalahan yang dilakukan siswa laki-laki dan perempuan.

1. Kesalahan Membaca

Siswa diklasifikasikan melakukan kesalahan membaca jika siswa salah dalam menginterpretasikan makna redaksi soal cerita yang diberikan. Siswa mencapai tahap ini apabila siswa dapat membaca masalah (Praktitipong \& Nakamura, 2006). Dalam penelitian ini kesalahan membaca yang dilakukan siswa lakilaki dan perempuan adalah salah menginterpretasikan makna redaksi soal sehingga siswa salah dalam menuliskan "apa yang diketahui" dan atau "apa yang ditanyakan" dalam soal.

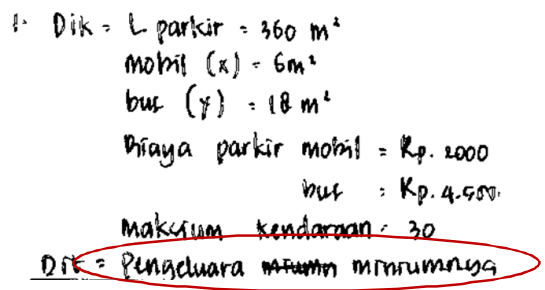

Gambar 1. Kesalahan Membaca pada Soal Nomor 1

Berdasarkan Gambar 1, siswa salah menuliskan apa yang ditanyakan dalam soal. Hal tersebut dikarenakan siswa tidak teliti dalam membaca soal.

Berdasarkan hasil wawancara, diketahui penyebab kesalahan membaca pada siswa laki-laki yaitu siswa tidak paham maksud soal dan penyebab kesalahan membaca pada siswa perempuan yaitu siswa tidak teliti dalam membaca soal. Hasil ini relevan dengan penelitian Zaidy yang menyatakan faktor penyebab kesalahan siswa antara lain kurangnya ketelitian dalam membaca dan tidak memahami maksud soal (Zaidy \& Lutfianto, 2016).

2. Kesalahan Memahami

Siswa diklasifikasikan melakukan kesalahan memahami jika siswa tidak dapat menuliskan atau menjelaskan informasi yang diketahui dan ditanyakan dalam soal, serta siswa tidak mengerti maksud kalimat yang 
diajukan dalam soal. Siswa mencapai tahapan ini apabila siswa dapat menjelaskan apa permasalahannya (Praktitipong \& Nakamura, 2006). Dalam penelitian ini kesalahan memahami yang dilakukan siswa lakilaki dan perempuan adalah tidak memahami makna kalimat yang diajukan dalam soal seperti kalimat yang mengandung kata maksimum dan minimum, tidak lengkap menuliskan informasi yang diketahui dan atau yang ditanyakan dalam soal, serta tidak menuliskan "apa yang diketahui” dan atau "apa yang ditanyakan" dalam soal dan menuliskan jawaban sembarang. Hal ini sesuai dengan penelitian Zaidy yang menyatakan kesalahan memahami yang dilakukan siswa antara lain tidak menyajikan apa yang diketahui, tidak menyajikan apa yang ditanyakan, dan tidak mengetahui apa maksud dari pertanyaan (Zaidy \& Lutfianto, 2016). Selain itu siswa lakilaki juga melakukan kesalahan menuliskan "apa yang diketahui” dan "apa yang ditanyakan" sama persis dengan soal tetapi tidak melanjutkan proses.

$$
\text { 2. Diket }=I=8 x+3 y
$$

\section{Gambar 2. Kesalahan Memahami} pada Soal Nomor 2

Berdasarkan Gambar 2, siswa salah menuliskan apa yang diketahui dan tidak menuliskan apa yang ditanyakan dalam soal dikarenakan siswa tidak paham maksud soal secara keseluruhan.

Berdasarkan hasil wawancara, diketahui penyebab kesalahan memahami pada siswa laki-laki yaitu siswa tidak paham maksud soal, serta motivasi dan sumber belajar siswa masih kurang. Hasil ini medukung penelitian Wildana yang menyatakan faktor internal penyebab kesalahan diantaranya motivasi (Wildana, 2016). Penyebab kesalahan memahami pada siswa perempuan yaitu siswa tidak paham maksud kalimat dalam soal yang mengandung kata maksimum.

3. Kesalahan Transformasi

Siswa diklasifikasikan melakukan kesalahan transformasi jika siswa tidak dapat mengubah informasi pada soal ke dalam model program linear. Siswa mencapai tahapan ini apabila siswa dapat menentukan operasi dan prosedur matematika yang sesuai atau siswa dapat mengubah dari pemahaman linguistik ke interpretasi matematis (Praktitipong \& Nakamura, 2006). Dalam penelitian ini kesalahan transformasi yang dilakukan siswa laki-laki adalah tidak mengubah informasi pada soal kedalam model program linear, salah menuliskan fungsi kendala atau fungsi tujuan, tidak lengkap menuliskan fungsi kendala, dan tidak menuliskan fungsi tujuan. Adapun kesalahan transformasi yang dilakukan siswa perempuan adalah salah memisalkan objek pada soal, salah menuliskan fungsi kendala atau fungsi tujuan, tidak lengkap menuliskan fungsi kendala, dan tidak menuliskan fungsi tujuan. Hasil ini mendukung penelitian Sardin yang menyatakan kesalahan-kesalahan yang dilakukan siswa dalam menyelesaikan soal program linear diantaranya adalah 
kesalahan membuat model matematika (Sardin \& Manurung, 2016).

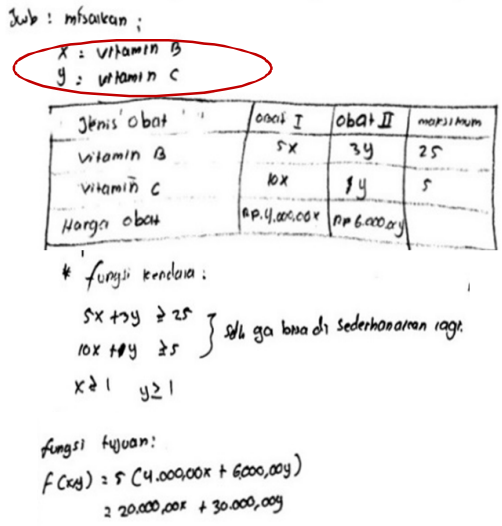

Gambar 3. Kesalahan Transformasi pada Soal Nomor 2

Berdasarkan Gambar 3, siswa salah memisalkan objek pada soal. Siswa memisalkan $\mathrm{x}$ sebagai vitamin $\mathrm{B}$ dan $\mathrm{y}$ sebagai vitamin $C$, dimana seharusnya $\mathrm{x}$ dimisalkan sebagai obat $\mathrm{I}$ dan $\mathrm{y}$ dimisalkan sebagai obat II. Hal ini dikarenakan siswa tidak teliti memisalkan objek pada soal.

Berdasarkan hasil wawancara, diketahui penyebab kesalahan transformasi yang dilakukan siswa laki-laki yaitu tidak teliti dalam menuliskan jawaban, tidak terbiasa mengerjakan soal yang lebih variatif, dan sumber belajar yang kurang. Berdasarkan hasil observasi di kelas XI MIPA 1, diketahui sumber belajar siswa masih kurang, dimana sebagian besar siswa tidak menggunakan buku paket saat proses pembelajaran berlangsung. Adapun penyebab kesalahan transformasi yang dilakukan siswa perempuan yaitu tidak teliti dalam memahami kalimat pada soal dan tidak paham cara memisalkan objek pada soal. Hasil ini relevan dengan penelitian Zaidy yang menyatakan faktor penyebab kesalahan siswa antara lain kurangnya pengetahuan dan keterampilan dalam mengubah kalimat verbal ke kalimat matematika serta kurang latihan mengerjakan soal-soal program linear yang variatif (Zaidy \& Lutfianto, 2016).

4. Kesalahan Keterampilan Proses Siswa diklasifikasikan melakukan kesalahan keterampilan proses apabila siswa tidak dapat menyelesaikan model program linear yang diperoleh dengan benar. Siswa akan mencapai tahap ini apabila siswa dapat melakukan proses perhitungan matematis secara benar dengan tahapan yang benar (Praktitipong \& Nakamura, 2006). Dalam penelitian ini kesalahan keterampilan proses yang dilakukan siswa laki-laki adalah salah menyederhanakan persamaan atau pertidaksamaan, salah dalam proses eliminasi dan substitusi, dan ada langkah-langkah yang dilewatkan atau tidak dituliskan. Kesalahan keterampilan proses yang dilakukan siswa perempuan adalah salah menyederhanakan persamaan atau pertidaksamaan, salah menggambar garis dari persamaan garis, salah menentukan titik pojok daerah penyelesaian, salah dalam proses eliminasi dan substitusi, dan salah perhitungan dalam menentukan nilai optimum. Hasil ini mendukung penelitian Zaidy yang menyatakan bahwa kesalahan yang dilakukan siswa pada tahap keterampilan proses adalah kesalahan dalam proses eliminasi dan substitusi (Zaidy \& Lutfianto, 2016). 
Entminasi:

$x+3 y=601.1 / x+3 y=60$

$x+y=30+\frac{1 / x+y 230}{3 y=30}=$

Subseresl:

$x+3 y=60$

$x+3 \infty)=60$

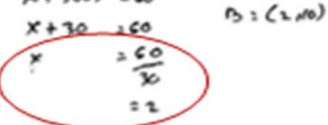

Gambar 4. Kesalahan Keterampilan Proses pada Soal Nomor 1

Berdasarkan Gambar 4, siswa salah dalam proses eliminasi dan substitusi dikarenakan siswa kurang memahami operasi hitung bentuk aljabar.

Berdasarkan hasil wawancara diketahui penyebab kesalahan keterampilan proses yang dilakukan siswa laki-laki yaitu tidak teliti dalam berhitung dan menuliskan jawaban, serta malas menuliskan langkahlangkah secara sistematis. Penyebab kesalahan keterampilan proses yang dilakukan siswa perempuan yaitu siswa kurang memahami materi prasyarat. Hal ini sesuai dengan penelitian Sardin yang menyatakan penyebab siswa melakukan kesalahan diantaranya kurang teliti dan tidak menguasai beberapa materi prasyarat (Sardin \& Manurung, 2016).

Alternatif solusi yang diberikan peneliti untuk meminimalisir kesalahan tersebut terjadi adalah sebagai berikut.

1. Kesalahan Membaca. Siswa dapat mengulangi dalam membaca soal serta mengecek apakah data yang dituliskan sesuai dengan soal.

2. Kesalahan Memahami. Siswa dapat mencari buku atau referensi lain untuk menunjang pemahaman siswa terhadap materi, serta bertanya kepada guru jika menemukan kalimat yang tidak dipahami. Guru juga dapat memotivasi siswa agar lebih giat dalam belajar.

3. Kesalahan Transformasi. Siswa dapat melihat objek apa yang ditanyakan dalam soal saat membuat pemisalan, banyak berlatih soal-soal cerita program linear yang lebih variatif, serta memperkuat pemahaman konsep prasyarat seperti persamaan dan pertidaksamaan linear.

4. Kesalahan Keterampilan Proses. Siswa dapat melatih kemampuan berhitungnya agar terhindar dari kesalahan komputasi, tidak tergesagesa saat mengerjakan soal, teliti dalam penulisan, memahami materi prasyarat, serta memperbanyak menyelesaikan latihan soal program linear secara sistematis dan jelas.

\section{KESIMPULAN}

Berdasarkan hasil penelitian dan pembahasan diperoleh kesimpulan sebagai berikut:

1. Kesalahan yang dilakukan siswa lakilaki dan siswa perempuan dalam menyelesaikan soal cerita program linear menurut teori Newman yang ditemukan selama penelitian yaitu:

a. Kesalahan membaca. Pada siswa laki-laki sebesar $21 \%$ dan pada siswa perempuan sebesar $10 \%$.

b. Kesalahan memahami. Pada siswa laki-laki sebesar $42 \%$ dan pada siswa perempuan sebesar $23 \%$.

c. Kesalahan transformasi. Pada siswa laki-laki sebesar $26 \%$ dan pada siswa perempuan sebesar $50 \%$.

d. Kesalahan keterampilan proses. Pada siswa laki-laki sebesar $11 \%$ 
dan pada siswa perempuan sebesar $17 \%$.

2. Faktor internal penyebab siswa melakukan kesalahan tersebut yaitu:

a. Tidak teliti, baik dalam berhitung, membaca soal, memahami soal, dan menuliskan jawaban.

b. Tidak menguasai materi prasyarat.

c. Motivasi belajar siswa masih rendah.

d. Tidak paham maksud soal atau kalimat yang diajukan dalam soal.

e. Tidak terbiasa mengerjakan soal yang lebih variatif.

f. Bingung memisalkan objek pada soal cerita.

Adapun faktor eksternal penyebab siswa melakukan kesalahan yaitu sumber belajar siswa yang belum cukup, seperti tidak ada buku paket.

Berdasarkan kesimpulan, saran yang dapat peneliti berikan untuk meminimalisir terjadinya kesalahan yaitu:

1. Bagi siswa laki-laki hendaknya dapat berlatih soal-soal cerita program linear untuk menambah pemahaman materi dan mencari buku paket atau referensi lain sebagai penunjang sumber belajar. Bagi siswa perempuan hendaknya teliti dalam memisalkan objek pada soal dengan melihat apa yang ditanyakan dalam soal, memperkuat pemahaman terhadap materi prasyarat, dan berlatih soal-soal yang lebih variatif agar terbiasa membuat model matematika.

2. Bagi guru hendaknya dapat sering memberikan latihan soal, serta mendorong motivasi belajar siswa.

\section{DAFTAR PUSTAKA}

Praktitipong, N., \& Nakamura, S. (2006). Analysis of Mathematics
Performance of Grade Five Students in Thailand Using Newman Procedure. Journal of International Cooperation in Education, 9(1), 111-112.

Santrock, J. W. (2007). Remaja. Erlangga.

Sardin, F. N., \& Manurung, M. M. H. (2016). Analisis Kesalahan Jawaban Peserta Didik dalam Menyelesaikan Soal-soal Program Linear di Kelas X Akuntansi SMK YPK Kotaraja Jayapura. Jurnal Ilmiah Matematika Dan Pembelajarannya, 3(1), 10-16.

Setyawati, N. (2010). Analisis Kesalahan Berbahasa Indonesia. Yuma pressindo.

Susanti. (2017). Analisis Kesalahan Siswa dalam Menyelesaikan Soal Cerita Program Linear Berdasarkan tahapan Newman. Jurnal Ilmiah Pendidikan Matematika, 2(6), 71-76.

Tarigan, H. G. (1988). Pengantar Analisis Kesalahan Berbahasa. Angkasa.

White, A. L. (2010). Numeracy, Literacy and Newman's Error Analysis. Journal of Science and Mathematics Education in Southeast Asia, 33(2), 129-148.

Wildana. (2016). Analisis Kesalahan Peserta Didik dalam Menjawab Soal Program Linear Kelas XII IPA MAN 1 Makassar. Jurnal Matematika Dan Pembelajaran Matematika, 4(1), 7582.

Zaidy, F., \& Lutfianto, M. (2016). Analisis Kesalahan Siswa dalam Menyelesaikan Soal Program Linear Berdasarkan Newman's Error Analysis (NEA) Ditinjau dari Kemampuan Matematika. Seminar Nasional Pendidikan Matematika Ahmad Dahlan, 297-303. 